\title{
PENGELOLAAN ZIS DI PERTAMINA DAK BALIKPAPAN
}

\author{
Oleh : H. Abd. Azis Al Bone
}

\section{PENDAHULUAN}

"Hai orang-orang yang beriman, infaqkanlah dijalan Allah, sebagian dari rezki yang telah kami berikan kepadamu sebelum datangnya hari yang pada hari (saat) ini tidak ada jual beli, tidak ada lagi persahabatan yang akrab dan tidak ada syafaat. Dan orang-orang kafir itulah orang-orang yang zalim "(albaqarah ayat: 254).

Umat Islam telah diwajibkan oleh Allah swt menginfakkan sebahagian dari hartanya untuk kepentingan umat manusia dan agama Allah swt:

Salah satu bentuk infak yaitu zakat termasuk ajaran dasar di dalam Islam. Banyak sekali ayat Alqur'an dan hadist Nabi Muhammad saw yang berisi perintah menunaikan zakat, antara lain, Firman Allah :

"Dirikanlah shalat dan bayarkan zakat" (An-Nisa ayat: 77 ).

Sehubungan dengan itu, ulama sepakat mengakui zakat sebagai salah satu rukun Islam yang penting dalam mengangkat harkat manusia. Meskipun ulama sepakat mengenai kedudukan zakat, namun pandangan mereka tentang penerapan ajaran zakat tidak selalu sama. Pemikiran ulama tentang zakat mengalami perkembangan sejalan dengan perkembangan keadaan dan zaman. Perbedaan pandangan tersebut dapat dilihat pada beberapa hal yang menyangkut : 1) jenis harta benda yang wajib dikenakan zakat, 2) orang atau lembaga yang berhak menghimpun dan mendistribusikan zakat dan 3) hal-hal yang dapat dibiayai dari zakat.

Sehubungan dengan adanya perbedaan pandangan itu, maka pandangan umat Islam pada tingkat awam juga menunjukkan adanya keragaman. Keragaman tersebut dapat dilihat dari kesadaran mereka dalam menunaikan zakat dan cara menyalurkannya.
Sudan menjadi tradisi bagi sebagian umat Islam menyalurkan zakat baik zakat fitri maupun zakat harta yang dilakukan secara langsung kepada orang atau lembaga yang dipandang berhak menerimanya. Ada yang menyerahkan kepada fakir miskin yang berdiam di lingkungan tempat tinggalnya, kepada petugas syara', guru-guru mengaji dan ada juga yang menyerahkan kepada panitia pembangunan masjid, Madrasah serta pengelola panti asuhan. Fenomena itu mencerminkan adanya kebebasan bagi para muzakki (pembayar zakat) dalam menyalurkan zakatnya kepada orang atau lembaga yang menerima menurut pilihannya sendiri. Hal ini mengisyaratkan masih adanya anggapan bahwa penyaluran zakat tidak harus melalui suatu lembaga secara formal.

Kebebasan bagi para muzakki di dalam menyalurkan zakatnya mempunyai segi-segi yang menguntungkan, namun tidak terlepas dari berbagai kelemahan. Dengan menyalurkan zakat secara langsung, para pembayar zakat ikut berperan di dalam menentukan halhal yang perlu dibiayai dengan zakat, dapat melihat secara langsung manfaat zakat yang dikeluarkan, membina hubungan baik dengan pihak penerima zakat, dan sebagainya. Selebihnya, cara tersebut dapat menyebabkan zakat tidak tersalurkan secara merata, yakni 
PENGELOLAAN ZIS DIPERTAMINA DAK BALDCPAPAN

ada pihak-pihak tertentu yang menerima banyak, sementara ada pula pihak lain yang kurang mendapat perhatian. Pemanfaatan zakat secara terencana, terpadu dan terkontrol sulit dilakukan, dan dapat mendorong lahirnya lembaga penghimpun zakat yang tidak bertanggung jawab dan sebagainya.

Berdasarkan pengamatan selintas dapat dikatakan bahwa hasil-hasil nyata yang dibiayai dari dana zakat masih terbatas, baik yang disalurkan perorangan maupun secara kelembagaan. Terbatas dalam arti jumlah orang, lembaga dan kegiatan yang dibiayai dengan zakat. Dalam arti penyaluran zakat lebih banyak diarahkan untuk hal-hal yang konsumtif. Bahkan penyaluran zakat cenderung bersifat karikatif tanpa diikuti oleh suatu upaya yang lebih produktif dan berkesinambungan. Padahal zakat berpotensi untuk rnelepaskan umat dari penderitaan, kemiskinan, dan mengangkat harkatnya kepada kehidupan yang lebih baik. Hanya saja tergantung terhadap sistim pengelolaan dan fungsionalisasi dari lembaga-lembaga penglolah zakat.

Atas dasar itu, gagasan untuk mengembangkan lembaga pengelolah zakat yang permanen dan profesional dipandang relevan oleh ulama dan cendekiawan muslim saat sekarang di Indonesia. Gagasan tersebut didukung oleh kalangan birokrasi pemerintah sehingga dibenttuk pengelolah zakat yang dikenal dengan BAZIS (Badan Amil Zakat dan Sedeqah) beberapa tahun yang lalu. Lembaga ini sudah terbentuk dan berjalan dibeberapa daerah tingkat satu dan dua dengan kondisi yang berfariasi.

Gagasan untuk mengadakan lembaga pengelolah zakat seperti itu sesungguhnya mempunyai dasar-dasar yang kuat dalam Alquran maupun Sunnah Nabi Muhammad saw. diantaranya firman Allah di dalam surah At-Taubah ay at 60 .

Adanya bagian khusus bagi pengelola zakat, memberi petunjuk akan perlunya lembaga khusus untuk mengelolah zakat tersebut. Secara khusus, Bazis Kalimantan Timur, tampaknya belum mendapat respon secara maksimal dari kalangan pembayar zakat. Bagi masyarakat yang berpendidikan dan memiliki wawasan dan semangat keberagamaan yang tinggi memang lebih memiliki kepedulian terhadap pembayaran zakat. Akan tetapi sebaliknya, masyarakat yang memiliki wawasan semangat keberagamaan yang rendah jelas tingkat kepeduliannya rtiembayar zakat juga rendah.

Begitu pula umat Islam di daerah ini masih banyak yang awam terhadap keberadaan Bazis. Sebagian lainnya mungkin lebih cenderung pada tradisi membayat zalat y\&ig sudah diakrabi untuk jangka waktu yang lamd atau ada lembaga lain pada level tertentu yang harus dipertahankan menurut aspirasi mereka, selain Bazis yang ada ditingkat Kabupaten dan Propinsi yang mengarah kepada suatu bentuk institusi yang bersifat nasional sebagaimana yang disarankan oleh Majelis Ulama Pusat ( Pelita, 5 April 95 ).

Demikian pula lembaga/badan atau amil zakat belum melakukan pengelolaan zakat secara profesional. Dana zakat yang diberikan kepada penerima zakat habis begitu saja, tanpa bisa dinikmati secara berkesinambungan. Hal ini terjadi, karena pemberian zakat kepada para penerima zakat, tidak diikuti dengan pembinaan yang dapat meningkatkan taraf hidup masyarakat. Oleh karena itu, pengelola zakat dalam upaya peningkatan taraf hidup keluarga muslim memiliki daya tarik tersendiri untuk ditelusuri. 
Penelitian ini dengan sasaran BAZIS Pertamina DAK Balikpapan yang telah berdiri pada 7 Agustus 1993. BUMN milik pemerintah dengan sistem managemen yang sudah maju ini tentu akan berpengaruh terhadap cara pengelolaan BAZIS Pertamina tersebut. Hal ini memungkinkan kerena pengurus BAZIS Pertamina tersebut adalah kariawan Petamina DAK Balikpapan.

Untuk itu pertanyaan yang ditampilkan dalam penelitian ini adalah bagaimana management pengelolaan BAZIS yang telah diterapkan oleh BAZIS Pertamina DAK Balikpapan?

Dalam penelitian ini diharapkan dapat menjawab pertanyaan dibawah ini.

1. Seperti apa keberadaan lembaga Bazis DAK Pertamina Balikpapan?

2. Bagaimana sistem pengelolaan zakat yang dilakukan oleh Bazis tersebut?

3. Bagaimana penggunaan/pemanfaatan zakat bagi para penerima zakat?

Tujuan penelitian adalah untuk menggambarkan keberadaan Badan/Amil zakat dan sistem pengelolaan zakat baik penerimaan maupun pendistribusian dalam kaitannya dengan penigkatan taraf hidup keluarga muslim.

Dan lebih khusus penelitian ini bertujuan :

a. Mengidentifikasi lembaga/badan amil zakat.

b. Mengungkapkan cara dan teknik pengelolaan zakat yang dilakukan amil zakat.

c. Mengetahui lebih jauh penggunaan zakat bagi penerima zakat.

d. Meneiusuri manfaat zakat dalam kaitannya dengan peningkatan taraf hidup.

Kegunaan penelitian adalah diharapkan dapat mengungkapkan berbagai hal yang berkaitan dengan pengelolaan zakat, baik pada pengumpulan maupun pada penyalurannya, khususnya mengetahui faktor pendukung dan faktor penghambat. Penemuan itu dapat membantu merumuskan metode yang efektif untuk menghimpun zakat secara maksimal dan upaya penyaluran yang lebih mengarah kepada peningkatan kualitas kemanusiaan.

Selanjutnya, penelitian akan berguna bagi pihak-pihak yang terkait, dengan pembinaan umat untuk mewujudkan lembaga pengelolah zakat maupun infak pada umumnya yang didukung oleh semua pmak antara lain, pemerintah daerah, aparat Departemen Agama, Majelis Ulama, BAZIS, Organisasi Keagamaan dan umat Islam pada umumnya.

Penelitian ini merupakan studi kasus di BAZIS Pertamina DAK Balikpapan tentang pengelolaan dana BAZIS baik penerimaan dan pemanfaatannya.

Pengumpulan data dilakukan dengan cara, wawancara mendalam dan pengamatan. Wawancara ditujukan kepada pengurus lembaga, untuk memperoleh informasi yang bersifat mendalam, baik menyangkut pengumpulan, pendistribusian, maupun pembinaan terhadap penerimaan zakat. Demikian pula wawancara dilakukan terhadap beberapa penerima zakat, khususnya yang menyangkut pendayagunaan zakat yang diterimanya. Pengamatan ditujukan untuk mengamati aktivitas yang dilaka'ukan oleh lembaga pengelolah zakat, dan kegiatan yang dilakukan oleh penerima zakat.

Data yang diperoleh melalui wawancara dan pengamatan dikategorisasi berdasarkan kerangka tertentu, kemudian dianalisis dan disajikan secara diskriptif. Interpretasi data dilakuakan berdasarkan temuantemuan yang telah ada dengan merujuk pada teori yang relevan. 
PENGELOLAAN ZIS DIPERTAMINA DAK BALIKPAPAN

\section{GAME ARAN UMUM}

\section{Sejarah Berdirirtya}

Pembentukan Bazis Pertamina DAK Balikpapan berdasarkan SK. PUD.KAL No. 137/C000/93-B 7 tanggal 7 Agustus 1993. Hal ini juga didorong oleh kenyataan bahwa selama ini pelaksanaan zakat, infaq dan shadaqah (ZIS) di lingkungan karyawan/wati. Pertamina belum dikoordinasi dengan baik. Akibatnya, ZIS belum dapat digunakan secara optimal dan mencapai daya guna dan hasil guna yang sebesar-besarnya bagi meningkatkan kesejahteraan umat.

ZIS merupakan potensi yang memungkinkan untuk digali mengingat karyawan/wati yang beragama Islam cukup besar dan sangat potensial untuk diarahkan partisipasi dan peran aktifnya dalam ZIS. Dengan demikian ZIS keluarga Pertamina ini dapat diarahkan untuk meninkatkan taraf hidup masyarakat.

Bazis Pertamina Pusat terlebih dahulu didirikan berdasarkan Surat Keputusan Pengurus Unit Korpri Pertamina No. Kep. 002/K.II/PUPER/1992 tanggal 10 Pebruari 1992. Bazis Pusat diketuai oleh Ir. Mochtar Effendi yang kebetulan menjabat Kepala Pusdiklat Pertamina, dan Dewan Pembina/Pengurus beberapa Direksi Muslim diantaranya Drs. F. Abda'oe.

Setelah Badan Dakwah Islam (BDI) Pusat berdiri, Ketua dan Sekretaris BDT Pertamina seluruh Indonesia diundang ke Jakarta untuk menjajaki berdirinya Bazis di tempat masing-masing. Ketua BDI DAK Balikpapan H. Sayhrial Buchari ikut hadir pada pertemuan tersebut, mendapat arahan dari Drs. H. Baharuddin (Pembina Bazis Pusat) dan beberapa pakar lainnya.

Ada beberapa keuntungan yang tampak bila bersama-sama menyatu dalam wadah ini antara lain, dengan bergabung/bersatu dalam mengumpulkan dana yang besar sehingga memungkinkan melaksanakan hal-hal yang besar manfaatnya dibandingkan bila bergerak sendiri-sendiri. Berkumpulnya dalam satu wadah akan lebih mempersatukan umat Islam di Pertamina, karena dapat bersama-sama menunaikan perintah Allah untuk meningkatkan kesejahteraan umat. Dengan meningkatkan hubungan baik dengan masyarakat sekeliling, maka citra Pertamina juga meningkat di lingkungan masyarakat. Pelaksanaannya lebih praktis, dirnana para pemberi ZIS tidak perlu bersusah payah mencari penerima zakat. Membantu saudara-saudara se Muslim yang sedang ditimpa musibah tidak hanya tetangga dekat. Mengurangi kesenjangan dan kecemburuan sosial antara golongan yang tidak berpunya dengan golongan yang berpunya.

Dari pengarahan-pengarahan di atas memotivasinya Pengurus BDI Pertamina seluruh Indonesia untuk segera membentuk organisasi Bazis di daerah masing-masing. Maka berdasarkan SK PUD. KAL No. 137/C000/93-B 7 tanggal 7 Agustus 1993 berdirilah organisasi Bazis Pertamina DAK Balikpapan dengan ketua umumnya Ir. H. Diponegoro Aribowo.

Bazis dibawah kepemimpinan beliau cukup berhasil dimana pada saat itu lebih banyak diarahkan pada zakat konsumtif, memberikan bantuan kepada fakir, miskin dan muallaf, bantuan kepada masyarakat transmigrasi, dan bantuan pembangunan Masjid, Mushalla, TPA dan sebagain^a.

Organisasi Bazis Pertamina DAK Balikpapan telah memiliki sebuah kantor yang permanen, bersebelahan dengan Koperasi "Al Mukminun" terletak di Jalan Sumbawa No. 10 Gunung Dub Kompleks Pertamina Kelurahan Prapatan Kecamatan Balikpapan Timur. Disinilah setiap hari 
berkantor seorang pelaksana harian Bazis Pertamina bernama Jumrani Iqbal, BA, yang telah bertugas sejak tahun 1993 sampai sekarang.

Jumrani berkedudukan sebagai pelaksana harian yang berkantor setiap hari sesuai jam kantor dengan menerima upah/gaji dari Badan Dakwah Islam (BDI) Pertamina. Oleh karena itu waktunya penuh dipergunakan hanya untuk kegiatan administrasi Bazis. Pada setiap hari Selasa malam (sesudah shalat Isya) pengurus Bazis mengadakan rapat rutin untuk membahas tentang program serta menerima laporan dari pelaksana harian tentang permintaan bantuan yang masuk ke sekretariat. Dengan demikian semua permasalahan berkaitan dengan managemen Bazis terlaksana dengan baik. Kalaupun ada suatu masalah yang harus segera mendapatkan kejelasan dari pimpinan Bazis, pelaksana harian Bazis dengan bebas menggunakan sarana komunikasi telpon langsung kepada pimpinan Bazis.

Perkantoran permanen dengan kelengkapan komputer, dan telepon telah memudahkan komunikasi antara para pengurus dengan sekretariat Bazis. Semua masalah tidak diselesaikan sendiri oleh Ketua Umum, tetapi melalui rapat rutin setiap Selasa malam.

Adapun lembaga Bazis ini diangkat oleh Surat Keputusan BDI Pertamina, yang dikeluarkan setiap tahun mulai Pengurus tahun 1993/1994, pengurus tahun 1994/1995 dan sekarang pengurus tahun 1995/1996. Pada tahun 1995/1996 yang menjadi Ketua Umum adalah Ir. H. Mora Sarumpaet.

Kalau melihat susunan pengurus tahun 1995/1996 ternyata dari Staf Ketua seperti Wakil Ketua I, Wakil Ketua II dan Wakil Ketua III tidak mengalami perubahan dengan pengurus sebelumnya, dalam arti bahwa hanya Ketua Umum yang berubah. Sedang administrasi keuangan masih tetap dijabat oleh Kami K dan Pieet Hidayat. Ketua bagian operasi dijabat oleh Ir. H. Fuadi Mahmud. Ketua Perencanaan dijabat oleh H. Hanardono, SE dan Ketua Keuangan dijabat oleh H.M. Djamil S.

Ada juga bidang yang secara operasional membuat rencana kegiatan masingmasing dan aktif mengadakan seleksi terhadap prioritas penggunaan dana untuk bidang masing-masing yaitu :

\section{Bidang Peribadatan :}

a. Menginventarisir bangunan peribadatan di lingkungan Pertamina, Balikpapan dan sekitarnya.

b. Menyusun peringkat Masjid/Mushalla yang memerlukan bantuan.

c. Inventarisasi daerah yang belum ada Masjid/Mushalla dan kemudian membuat prioritas.

d. Membangun Masjid/Mushalla sesuai prioritas.

e. Mengirim secara priodik para da'i ke daerah yang memerlukan (daerah transmigrasi, pedalaman).

\section{Bidang Sosial}

a. Inventarisasi Pondok Pesantren dan Panti Asuhan.

b. Memberikan sumbangan. kepada Pondok Pesantren/Panti Asuhan baik dalam bentuk uang, barang sesuai yang diperlukan dan proyek yang berkaitan dengan kesejahteraan mereka. Proyek ini dapat berupa bantuan peternakan ayam, kolam ikan, bengkel (sepeda.motor dan mobil), mesinjahit.

c. Memberi bantuan kepada golongan ekonomi lemah yang diprioritaskan kepada ekonomi lemah (pedagang kaki 


\section{PENGELOLAAN ZIS DI PERTAMINA DAK BALIKPAPAN}

lima) dengan jalan memberikan pimjaman tanpa bunga untuk modal usaha.

d. Membangun Klinik/Rumah Sakit Islam.

\section{Bidang Pendidikan}

a. Inventarisasi Taman Pendidikan atau sekolah-sekolah Islam dan menyusun prioritas yang memerlukan bantuan.

b. Inventarisasi siswa SLTA yang pandai tetapi tidak atau kurang mampu membiayai pendidikannya, kemudian memberikan beasiswa sesuai prioritas. Inventarisasi bisa dilakukan dengan memberikan edaran ke sekolahsekolah/Perguruan Tinggi.

c. Memberikan bantuan berupa buku-buku baik umum maupun yang bernafaskan Islam ke daerah terpencil (transmigrasi) dan memberikan buku-buku Islam ke Perpustakaan Masjid.

Dari kegiatan yang menonjol selain dari ketiga bidang di atas adalah Bazis telah mendirikan Koperasi "Al Mukminun". Koperasi telah merekrut tiga orang tenaga kerja khusus untuk kegiatan pelayanan dan kebersihan. Koperasi yang didirikan sejak 19 September 1995 merupakan koperasi konsumen dengan berbagai ragam barang kebutuhan sehari-hari baik untuk keluarga danpara pelajar. Karena letaknya sangat strategis di tengah Kompleks Pertamina Gunung Dub dan berdekatan dengan lingkungan sekolah PERTAMINA. ternyata penjualan barang setiap harinya rata-rata $\mathrm{Rp} 200.000,-$. Dengan demikian penjualan perbulan mencapai Rp 6.000.000,-

Di samping itu pada tahun 1995, juga telah berhasil membangun klinik yang diberi nama Klinik Ibnu Sina. Menurut Iqbal sebagai pengurus harian Bazis bahwa setiap bulan menangani $\quad \pm 400-500$ pasien.
Klinik ini ditangani oleh enam dokter, dua orang perawat dan dua bidan. Penghasilan setiap bulannya rata-rata $\mathrm{Rp} 7$ juta, Klinik ini juga berfungsi sosial dimana bagi anak yatim dan fakir miskin dengan surat pengantar dari Lurah/Kepala Desa diberikan fasilitas yang penuh tanpa dipungut bayaran.

Pertemuan rutin pengurus Bazis setiap Selasa malam ternyata sangat efektif karena semua masalah dapat diselesaikan dengan tuntas. Hal ini dapat dilihat dalam penentuan prioritas bantuan yang diberikan selalu diikuti dengan penjajakan ke lapangan oleh satu tim sesuai keputusan rapat. Kemudian pada Selasa malam yang akan datang tim memberikan laporan dari hasil penjajakannya. Pada saat itu beberapa anggota mengomentari temuan yang ada di lapangan, dan kemudian ditentukan skala prioritas bantuan yang akan diberikan.

Tenaga sekretariat yang ditangani oleh Iqbal cukup efektif dan efesien karena tenaga ini yang selalu siap menerima surat permintaan bantuan dan secara langsung menerima tamu yang menyampaikan permohonan modal usaha atau bantuan lainnya. Kemudian pada setiap Selasa malam, secara rinci pelaksana harian melaporkan dalam rapat dan metalui rapat ditentukan langkah selanjutnya. Yang menarik disini adalah semua bantuan diberikan harus melalui penelitian yang cermat dan pengawasan yang ketat.

Kegiatan yang pada awalnya lebih banyak dana digantungkan pada Mustahiq, tetapi pada periode 1994/1995 dengan kegigihan pengurus Bazis telah dapat mendirikan dua kegiatan produktif Bazis dalam mendapatkan dana tambahan yaitu lewat Koperasi dan Klinik. Dan kalau prioritas awal dana bazis diarahkan pada bantuan konsumtif kepada fakir miskin, daerah transmigrasi dan daerah pedalaman, dan pembangunan sarana ibadah, maka pada 
PENGELOLAAN ZIS DI PERTAMINA DAK BALIKPAPAN

periode 1995/1996 dana lebih banyak diorientasikan pada program pemerintah yaitu peningkatan kualitas sumber daya manusia berupa dana beasiswa.

\section{AKTIVITAS BAZIS DALAM KAIT - ANNYA DENGAN PENGELOLAAN ZAKAT}

\section{Proses Penghimpunan Dana}

Langkah-langkah awal untuk menghimpun dana, diawali dengan berusaha mendapatkan dukungan dari para karyawan. Untuk maksud tersebut maka diadakan ceramah-ceramah umum pemantapan Bazis, yang pertama kali pada bulan Agustus 1993 di Masjid Istiqamah Pertamina Balikpapan, dengan penceramah K.H. Hasan Basri (Ketua MUI Pusat). Pada kegiatan ceramah tersebut dihadiri oleh para pejabat Pertamina dan karyawan serta keluarganya.

Selanjutnya diselenggarakan pemantapan ZIS yang khusus dihadiri pejabat eselon di lingkungan Pertamina Balikpapan dengan penceramah H. Abdul Syakur Thawil dari Surabaya. Dan setiap khatib dan muballiq tetap memberikan khotbah atau ceramah dititipkan agar memesankan pentingnya ZIS.

Setelah lebih kurang sebulan mencari dukungan melalui ceramah agama dan khotbah maka pengurus Bazis memulai kegiatan berikutnya dengan membuat surat edaran untuk meminta kesediaan karyawan mengeluarkan ZIS melalui pemotongan gaji semenjak bulan September 1993.

Pada edaran pertama eselon IV sampai eselon tertinggi (eselon II) dengan mudah dapat dimonitor dan hasilnya $100 \%$. Selanjutnya Bazis memonitor ketat dengan mendatangi atau menanyakan kepada koodinator administrasi, tentang anggota Bazis pada masing-masing bidang. Selanjutnya, khusus pada bidang eksplorasi dan Papum, berupaya mengadakan pemanggiian semua karyawan/wati Muslim untuk dihimbau dan diajak diskusi. Hasilnya ternyata sangat memuaskan $100 \%$ ikut berpartisipasi.

Inventarisasi perolehan ZIS hasil edaran pertama dan kedua dari masingmasing bidang, $61 \%$ sudah menyetujui. Selanjutnya, hasil perolehan ZIS dilaporkan kepada pimpinan Pertamina Balikpapan dan dimohon manager untuk menghimbau lagi pada pengajian yang akan datang. Himbauan manager ternyata berhasil dimana hasil peroleh ZIS meningkat $80 \%$. Selanjutnya yang belum ber ZIS diundang untuk dihimbau dan diskusi. Ternyata usaha tersebut berhasil. Jumlah yang aktif dalam menyampaikan ZIS mencapai 1.794 orang. Pada tahun 1994/1995 meningkat mencapai 3.000 orang, tetapi pada tahun 1995/1996 menurun drastis menjadi 2700 orang. Hal ini disebabkan lahir SK No. 09 dengan mempercepat masa pensiun dan di samping itu adanya pemindahan karyawan bidang eksplorasi dari DAK Balikpapan.

Dana ZIS setiap bulannya mencapai rata-rata $R p 20$ juta. Dana ZIS disimpan pada rekening Bank, yaitu Bank Dagang Negara Cabang Balikpapan. Dengan demikian dana ZIS dianggap cukup aman. Adapun pengeluaran uang melalui prosedur administrasi yang ketat. Di samping itu pengawasan terhadap penggunaan dana ZIS cukup ketat karena dalam lembaga BAZIS ini memiliki petugas pengawas dari Akuntan Pertamina yang profesional.

\section{Proses Penyaluran}

Adapun penyaluran dana Bazis secara utuh diarahkan untuk pembangun-an Islam mengacu pada penentuan asnaf dalam ketentuan Alquran. Bahkan sekretariat Bazis yang 
bertugas secara rutin di kantor Bazis diberi gaji oleh Badan Dakwah Islam (BDI) Pertamina. Sedang petugas lain seperti pesuruh, dan petugas koperasi diberi upah oleh Bazis.

Dalam menyalurkan dana Bazis diarahkan pada tiga bidang utama yaitu bidang peribadatan, bidang pendidikan dan bidang sosial.

\section{Bidang Peribadatan}

Dalam menangani bantu an bidang peribadatan khususnya Masjid/ Mushalla ada beberapa langkah yang dilakukan antara lain :

a. Menginventarisir semua usulan atau permohonan yang masuk kepada sekretariat Bazis.

b. Melakukan penjajakan langsung ke lapangan, untuk menentukan susun-an peringkat Masjid/Mushalla yang memerlukan bantuan sekaligus kebutuhan apa saja yang diperlukan dalam penyelesaian bangunan tersebut.

c. Menyusun peringkat Masjid/Mushalla yang memerlukan bantuan melalui rapat rutin pengurus Bazis setiap Selasa malam.

d. Bantuan diberikan secara bertahap dalam bentuk material dan juga uang untuk biaya tukang.

Dalam kondisi yang lain, bila ada permohonan dari suatu daerah yang belum mempunyai Masjid/Mushalla, maka tim mengadakan peninjauan ke lokasi-lokasi, kemudian membuat skala prioritas. Pada waktu akan dibangun, maka Bazis mengirimkan bantuan berupa material sesuai kebutuhan secara bertahap, sedang masyarakat secara bergotong royong membangunnya.

Jumlah Masjid/Mushalla yang mendapat bantuan dari Pertamina cukup besar antara lain :

(1) Masjid Al Hidayah km 28 Samboja, tahapan pertama Bazis menyediakan dana Rp 10 juta.

(2) Masjid Pesantren Al Hay at di km 36 arah Samarinda, setelah ditinjau pengurus Bazis, pekerjaan mencapai $75 \%$. Untuk mempercepat terwujudnya, Bazis membantu material bangunan senilai Rp 4.500.000,-.

(3) Mushalla Babussalam, Kampung Baru Tengah. Bazis membantu material senilai Rp 1.344.000,-

(4) Masjid Al Muhajirin Kariangan, desa transmigrasi. Bazis memberi bantuan baik air, dengan mengirimkan material dan upah kerja senilai Rp 739.300,-

(5) Masjid Al Ikhlas, Gunung Seteleng Penajam. Bazis memberikan bantuan berupa material seharga Rp 3.462 500,-

(6) Mushalla Al-Furqan Kecamatan Warn. Mushalla yang berlokasi di Km 30 arah Tanjung mendapat bantuan Bazis berupa ^material seharga Rp 1.620.000,-

(7) Masjid Nurul Amin Gunung Intan.

Bazis memberikan bantuan material senilai Rp 9,1 juta, yang tahap pertama diserahkan Rp 2.000.000,- 
PENGELOLAAN ZIS DI PERTAMINA DAK BALIKPAPAN

\section{Mengirim secara periodik para Da'i ke Daerah}

Dalam rangka peningkatan kualitasnya imam masyarakat Islam pedesaan, khususnya daerah transmigrasi dan sekitarnya, maka Bazis menyediakan kader da'i yang dipersiapkan khusus untuk daerah pedalaman. Mereka mengabdikan diri sebagai da'i dan khatib di daerah pedalaman yang dikirim secara periodik. Bazis memberikan honor tetap setiap bulan Rp 150.000,-. Da'i dikirim antara lain ke :

(1) Mushalla Al Furqan, Km 30 arah Tanjung merupakan daerah transmigrasi sejak tahun 1966 asal Jawa.

(2) Desa Gunung Intan Km 30

(3) Desa GiriMukti Km 20 Kab. Pasir

(4) Desa Semoi dan Sepaku Km 39

(5) Desa Tani Bakti Km 36

(6) Desa Tani Bakti Samboja Km 28 transmigrasi lokal gusuran Hutan Lindung Bukit Suharto.

(7) Desa Kariangan Km 5,5 arah Samarinda.

\section{Bidang Pendidikan}

Semua ini dilaksanakan melalui prosedur yang sama dengan pembangunan rumah ibadah yaitu melalui penjajakan ke lokasi bangunan kemudian disusun sesuai urutan prioritas dan selanjutnya diberi bantuan secara bertahap.

Adapun pembangunan gedung TPA/TKA yang mendapat bantuan Bazis Pertamina adalah :

(1) TKA/TPA Jabal Nur Prapatan Jumlah santri mencapai 100 santri yang harus belajar berhimpitan di
Mushalla Jabal Nur. Maka Bazis memberikan bantuan material senilai Rp 2.940.000,- pada tahap pertama penambahan ruangan belajar dan pada tahap kedua Bazis memberikan tambahan senilai Rp 3.157.500,-

(2) TKA/TPA Nurul Ibadah, Gunung Pasir

Masjid Nurul Ibadah Balikpapan merangkap fungsinya untuk kegiatan belajar 130 santri yang dibagi 4 kelas. Tempat belajar yang lebih layak sedang disiapkan, dan baru terwujud tiang pancang kayu ulin. Bazis mempercepat terwujudnya dengan memberikan bantuan material senilai $\mathrm{Rp} 2.725 .000$,-

(3). Honor Guru dan Santuan Imam Masjid

Bazis memberikan bantuan honor guru dan santunan imam masjid juga melalui pengamatan yang teliti, kemudian menentukan skala prioritas. Misalnya khusus guru TPA/TKA, hanya apabila terdapat kemungkinan penambahan guru sedang penguru TPA/YKA tidak mempunyai dana maka Bazis akan dapat memberikan bantuan.

Beberapa guru dan imam masjid yang mendapat bantuan antara lain :

(a) Nurul Khair Prapatan.

Kegiatan belajar diikuti oleh 100 anak pada pagi dan sore hari. Tenaga pengajar sebanyak 6 orang sibuk dan akan merekrut guru baru, namun dihadapkan pada kendala keterbatasan dana untuk honor guru. Bantuan yang 
diberikan Bazis berupa honor beberapa guru sebesar Rp 150.000,- setiap bulan. Direncanakan diberikan selama 6 bulan sehingga dana yang dipersiapkan Rp 900.000,-.

(b) Nurul Khair, Batu Ampar.

Kegiatan belajar yang diselenggarakan yayasan ini menempati Mushalla Nurul Khair yang tidak bisa dikatakan layak. Lokasinya di Km 5,5 Batu Ampar bekas lokalisasi WTS, mengasuh 118 anak belajar di tingkat Ibtidaiyah, Diniyah dan TK/TPA.

Yayasan tidak bisa memungut biaya dari siswa karena pernah dipungut Rp 5.000,-/bulan, akibatnya murid tidak ada yang masuk sekolah, kata pengurus yayasan.

Delapan staf pengajar diuji ketabahannya harus mengajar pagi dan sore tanpa honor. Bazis bertekad agar proses belajar berlangsung terus, dengan memberikan bantuan sarana senilai $\mathrm{Rp}$ 1.000.000,- dan honor guru untuk dua bulan Rp 150.000,-.

(c) TPA Masjid Al Muhajirin Kariangan.

Sebanyak 93 siswa dengan 11 orang guru, belajar dengan sarana minim di ruangan masjid. Bazis memberikan bantuan perlengkapan sekolah dan honor guru Rp 1.332.000,-

(d) TPA Firdaus, Kampung Damai. Mereka merupakan masyara- kat pindahan dari eks lokasi kebakaran Klandasan dan Kampung Baru Balikpapan, sebagiannya menempati Rumah Sangat Sederhana (RSS) di kampung Damai.

Sebanyak 120 anak belajar dengan 11 tenaga pengajar sukare1a. Untuk itu Bazis memberikan bantuan honor guru Rp 900.000,untuk 6 bulan.

(4) Dalam kualitas sumber daya manusia. Bazis mengeluarkan dana berupa bea siswa sebesar 576 siswa SD, SMP, SLA, dan Perguruan Tinggi. Khusus Perguruan Tinggi hanya 30 orang, SLA 485 orang, SLTP 30 orang dan SD 26 orang. Bagi SD diberikan Rp $24.000,-$ /bulan yang dikirmkan lewat sekolahnya. Bagi SLTP/SLTA diberikan Rp 60.000,-/bulan yang dikirimkan lewat Pengurus Masjid.

Perguruan Tinggi diberikan Rp 80.000,-/bulan diterima oleh yang bersangkutan. Khusus dalam rangka pembinaan dari Bazis secara langsung diadakan ceramah sekali 3 bulan yang diadakan di masjid tertentu. Sedang pembinaan rutin setiap bulan diadakan oleh Pengurus Masjid yaitu diadakan pada malam Ahad awal bulan.

Bila ada diantara penerimaan Bea Siswa yang menyimpang dari akhlak Islam seperti minum minuman keras, berjudi dan sebagainya, maka kepadanya diberikan nasehat secara khusus oleh pengurus masjid. Bila sudah dinasehati dua kali oleh pengurus masjid tapi yang bersangkutan tidak menunjukkan perubahan, maka 
Pengurus Bazis memberikan peringatan tertulis dan bita hal itu juga tidak digubris maka dengan terpaksa bea siswanya distop.

\section{Bidang Sosial}

(a) Memberikan sumbangan kepada Pondok Pesantren/Panti Asuhan.

- Kepada 6 pesantren diberikan sumbangan rutin setiap bulan berupa beras masing-masing $500 \mathrm{~kg}$.

- Juga diberikan bantuan berupa peternakan ayam, kolam ikan, bengkel (sepeda, motor dan mesin jahit) sesuai kebutuhan.

- Memberikan 100 Alquran dan terjemahannya kepada dua pesantren dan Panti Asuhan.

(b) Masjid di Kompleks Pertamina.

Imam masjid dan petugas masjid selama ini mendapat honor dari perusahaan. Namun jumlahnya tidak mencukupi untuk menunjang keperluan sehari-hari.

Bazis memberikan tambahan honor kepada mereka yang mengelola 11 masjid di kompleks perumahan Pertamina Balikpapan jumlahnya Rp 2.446.000,- dimana masing-masing Imam mendapat tambahan honor dari Bazis Rp 150.000,-/bulan.

(c) Memberikan modal tanpa bunga yang diprioritaskan kepada ekonomi lemah (pedagang kaki lima).

No. 13 Th. VIII Juli/Desember 1996
- Sayid Muhammad mendapat bantuan modal sebesar RP 3.000.000,-, dengan sistem membayar angsuran Rp 150.000/buIan. Demikian juga dengan 6 orang pedagang kaki lima lainnya.

- Tukang ojek seperti Sukirman dan Suparman yang mendapat bantuan modal Rp 2.000.000,- masingmasing dengan mencicil Rp 150.000,-/bulan ternyata merasakan betapa besar manfaat bantuan Bazis mengangkat kehidupan mereka. Demikian pula dengan 2 tukang ojek lainnya.

- Memberikan modal kepada usaha bengkel motor/kulkas. Mereka diberi modal masing-masing Rp 1.000.000,-

Ada bengkel yang diberik bantuan dan berhasil :

- Pinjaman modal kerja kepada Imam masjid Al Muthmainal Kompleks Pertamina Gunung Balikpapan mendapat bantuan pinjaman modal Rp 1.000.000,- yang dicicil Rp 50.000,-/bulan. hal ini dimaksudkan agar yang bersangkutan dapat menambah penghasilan keluarga, sehingga lebih menaruh perhatian untuk memakmurkan masjid dan meningkatkan derajat sosial Imam masjid. *

(d) Santunan kepada Fakir :

(1) Bantuan pengobatan

F yang menderita kanker kulil mendapat bantuan pengobatan dari Bazis. Iadikirimke 
Rumah Sakit DR. Sutomo Surabaya utnuk tahap pertama Bazis membantu Rp 2.000.000,--

(2) 2000 Paket Ramadhan

Pada tahun 1994/1995 disiapkan 1000 paket Ramadhan dengan tujuan agar umat Islam dapat menyambut Ramadhan tidak dengan kesedihan, tetapi dengan kegembiraan. Maka Bazis menyediakan paket Ramadhan yang berisi setiap paketnya berupa $5 \mathrm{~kg}$ beras,, $1 \mathrm{~kg}$ gula dan $1 \mathrm{~kg}$ terigu. Untuk tahun 1995/1996 jumlah paket Ramadhan ditingkatkan menjadi 2000 paket. Paket tersebut dibagikan kepada warga transmigrasi Kabupaten Pasir antara lain Desa Gunung Intan (Km 30), Giri Mukti dan sekitarnya (Km 20). Desa lainnya yang menerima, Desa Semoi dan Sepaku (Km 39), Desa Tani Bakti (Km 36), Desa Kariangan (Km 5,5) arah Samarinda.

Pemberian paket juga dimaksudkan untuk lebih memberikan perhatian terhadap Muslim (fakir) di pedesaan, yang umumnya kurang mendapatkan perhatian, dan yang lebih penting agar masyarakat pedesaan tidak mudah meninggalkan aqidah.

(3) Klinik Ibnu Sina, selain digunakan untuk meningkatkan pendapatan dana Bazis dan membuka lapangan kerja, juga punya tujuan sosial yaitu memberikan pengobatan cuma-cuma kepada orang yang tidak mampu, fakir miskin dan anak yatim serta janda. Untuk itu disyaratkan membawa surat pengantar dari Lurah/Kepala Desa setempat.

\section{Beberapa Kasus Zakat Produktif}

a. M sebagai pedagang kecil kaki lima dengan usaha berjualan barang keperluan sehari-hari, mendapat pinjaman dari Bazis sebesar Rp 3.000.000,-. Dengan modal tersebut, ia berhasil melengkapi dagangannya dengan semua barang keperluan sehari-hari. Menurut M, barang keperluan sahari-hari mulai dari jarum, benang, rokok, kopi, teh, beras, gula, terigu, sabun, odol, sikat gigi dan sebagainya selalu tersedia. Konsumen yang terdiri dari masyarakat sekitarnya bertambah banyak dari hari ke hari. Penjualan meningkat dan keuntungan menjadi lebih besar, $M$ dapat mengembangkan tokonya sehingga lebih besar dari yang semula.

Pembayaran cicilan, setiap bulan sebesar Rp 150.000,- dapat dipenuhinya tepat waktu sesuai perjanjian dengan Bazis. Dengan demikian Bazis Pertamina dirasakan manfaatnya dalam mengangkat tingkat kehidupan kaum dhuafa.

b. SK, seorang tukang ojek yang selama ini hidup miskin, ternyata mendapat pinjaman modal dari Bazis sebesar Rp 2 juta untuk membeli motor sebagai ojek untuk mata pencaharian sehari-hari.

Menurut Sukirman dari usaha ojek tersebut, rata-rata sehari dia dapat mengumpulkan penghasilan mencapai $\mathrm{Rp}$ 15.000,-. Dia harus menyimpan untuk cicilan perbulan Rp 150.000 ,- dalam arti sehari Rp 5.000,-, Rp 7.000,- digunaka 


\section{PENGELOLAAN ZIS DI PERTAMINA DAK BALIKPAPAN}

untuk belanja sehari-hari keluarga dan Rp 3.000,- harus ditabung di Bank untuk keperluan yang mendadak. Dengan lunasnya cicilan setelah +14 bulan sekarang dia sudah lega dan dapat membangun rumah lebih baik serta mengaktifkan isteri untuk berjualan di rumah.

c. SH pemilik bengkel kulkas yang pada awalnya hidup menumpang di rumah familinya. Pada bulan Pebruari 1995, melalui seorang teman mencoba meminta modal kepada Bazis untuk mendirikan sevice Kulkas. Dari Bazis didapatkan pinjaman modal sebesar Rp 2.000.000,-. Pada Bulan April 1996 pinjaman sudah lunas. Sekarang sudah mengambil rumah cicilan, dan alhamdulillah perabot rumahnya sudah lengkap.

\section{Pola Pembinaan}

Khusus bagi para mustahiq yang terdiri dari mereka yang mendapat bea siswa dan mereka yang mendapat bantuan modal dari Bazis, mereka dibina melalui beberapa pola pembinaan.

\section{Penerima Bea Siswa}

Sebagaimana telah disinggung pada pasal di muka bahwa untuk mendapatkan bea siswa memiliki persyaratan tertentu :
a. Surat Keterangan dari Sekolah
b. Rekomendasi dari Pengurus Masjid dalam lingkungannya
c. Surat Keterangan dari Lurah/Kepala Desa.
Dengan adanya surat rekomendasi dari pengurus masjid diharapkan dengan kerja- sama yang baik dengan pengurus masjid, maka penerima bea siswa dapat dibina

mentalnya. Pengurus masjid, berdasarkan surat permintaan dari Pengurus Bazis Pertamina, mengadakan pengajian rutin khusus bagi penerima bea siswa. Masjid yang ditunjuk mengadakan pembinaan ini tidak semua masjid tetapi masjid tertentu yang bisa dijangkau oleh para penerima bea siswa. Mereka dibina dalam bentuk kegiatan pengajian rutin dua minggu sekali yaitu setiap minggu kedua dan minggu keempat ba'da Ashar. Kegiatan ini diadakan atas dasar kerjasama dengan Pengurus Bazis Pertamina.

Selain dari kegiatan rutin pengajian di atas, juga diadakan sekali sebulan pertemuan dengan Pengurus Bazis Pertamina yang diawali dengan ceramah agama dengan penceramah didatangkan oleh pengurus Bazis Pertamina. Dan sebelum acara ditutup, diadakan pengarahan khusus dari pengurus Bazis tentang akhlak Islam dan diadakan dialog tentang berbagai masalah.

Dalam rangka menegakkan akhlak Islam maka bagi penerima bea siswa yang melakukan prilaku amoral seperti perkelahian, pencurian, minum minuman keras, zina dan sebagainya maka secara langsung akan mendapat teguran dari pengurus masjid scbagai pcmhina mereka. Uila sampai dua kali teguran ternyata tidak digubris oleh penerima bea siswa, maka secara tertulis akan mendapat peringatan keras dari pengurus Bazis, dan hal ini merupakan peringatan terakhir. Bila seorang ^penerima bea siswa masih melakukan prilaku amoral sesudah peringatan terakhir maka bea siswa dihentikan.

Demikian pola pembinaan bagi para penerima bea siswa tingkat SD sampai SLA. 
PENGELOLAAN ZIS DI PERTAMINA DAK BALIKPAPAN

\section{Penerima Modal}

Upaya pembinaan bagi mereka yang mendapatkan modal usaha dari Bazis adalah dengan mengikuti kegiatan pengajian rutin yang diadakan di Masjid Istiqamah sekali sebulan. Pelaksanaan kegiatan pengajian ini diadakan pada awal bulan pada Jum'at pertama. Pada waktu itu sekaligus mereka menyerahkan setoran cicilan pinjaman mereka. Beberapa pengurus mengambil waktu untuk memberikan arahan berkaitan dengan usaha dan pemanfaatan uang yang ada. Ke- mudian dilanjutkan dengan dialog atau diskusi.

Demikian gambaran tentang pola pembinaan bagi mustaliq, khususnya mereka yang mendapatkan bea siswa dan mereka yang memperoleh pinjaman modal usaha.

\section{PENUTUP}

\section{A. Kesimpulan}

Dari uraian yang ditampilkan pada bab-bab terdahulu dapat disimpulkan sebagai berikut :

1. Pengelolaan dana Bazis Pertamina DAK Balikpapan merupakan inisiatif

${ }^{\kappa}$. Pertamina Pusat Jakarta dalam rangka mengakumulasi dana Pertamina melalui lembaga zakat, infaq, dan shadaqah. Dana yang dikumpulkan tersebut selain dalam rangka beribadah kepada Allah, juga untuk tujuan sosial. Dana Bazis Pertamina diharapkan mampu mengangkat tingkat kesejahteraan masyarakat di sekitarnya sebagai wujud kepedulian keluarga besar Pertamina, juga dengan demikian citra Pertamina semakin baik di mata masyarakat. Dengan demikian sekaligus mengurangi kesejahteraan dan kecemburuan sosial.

2. Managemen pengelolaan dana Bazis Pertamina telah dilaksanakan secara proporsional dan penuh tanggung jawab. Hal ini dapat dilihat dari kelengkapan administrasi Kantor Bazis yang didukung oleh sarana komputer dan telepon sehingga komunikasi antara pelaksana harian dengan pimpinan dan pengurus Bazis tetap lancar setiap hari. Dana Bazis disimpan melalui rekening Bank Dagang Negara Cabang Balikpapan. Sedang pengeluaran dana melalui prosedur yang ketat. Semua permohonan bantuan harus melalui administrasi yang jelas yang ditujukan kepada Bazis Pertamina. Kemudian pelaksana harian akan melaporkan semua permintaan bantuan tersebut pada rapat rutin Pengurus Bazis setiap Selasa malam di Masjid Istiqamah.

Keputusan tidak semata-mata di tangan Ketua tetapi melalui keputusan rapat. Melalui penjajakan lapangan tim yang ditunjuk kembali akan melaporkan hasil pengamatan lapangannya kemudian peserta rapat menentukan skala prioritas dari objek bantuan.

Bantuan yang diberikan disesuaikan dengan kebutuhan yang ada melalui perhitungan yang tepat. Bantuan yang diberikanpun tidak langsung berupa dana, tetapi material dan biaya tukang. Setelah disepakati baru dana dikeluarkan, dari Bank dengan seizin Ketua Bazis. 
3. Suatu hal yang menonjol dari Bazis Pertamina adalah selain ikut memikirkan zakat produktif dengan memberikan pinjaman modal tanpa bunga, juga mampu mendirikan Klinik Ibnu Sina Dan Koperasi konsumsi "Al Mukminun". Juga berfungsi sosial, dimana bagi anak yatim dan fakir miskin diberikan pengobatan secara cumacuma.

4. Bazis Pertamina juga ikut mensukseskan program pemerintah dalam rangka meningkatkan kualitas sumber daya manusia. Bazis memfokuskan dana Bazis selain untuk produktif juga bea siswa bagi anak yatim piatu dan fakir miskin yang berprestasi.

\section{B. Saran}

1. Dengan besarnya dana Bazis Pertamina sangat diharapkan kiranya bantuan berupa pisik yang berkaitan dengan pembangunan masjid/Mushalla agar dihentikan atau paling tidak dikurangi. Dan dana yang besar itu difokuskan untuk bantuan bea siswa dan bantuan modal dalam rangka meng-angkat harkat dan derajat umat Islam.

2. Kiranya Dana Bazis Pertamina jangan dibatasi hanya wilayah Kalimantan Timur dan sekitarnya tetapi diarahkan untuk mengangkat harkat masyarakat Islam Muallaf dari Propinsi TimorTimur dan Nusa Tenggara Timur yang banyak mengharapkan perhatian dan uluran tangan umat Islam.

No. 13 Th. VIII Juli/Desember 1996

\section{DAFTAR PUSTAKA}

1. Departemen Agama R1, Alquran dan Terjemahannya, Proyek Departemen Agama,

1971 Jakarta.

\section{INFO BAZIS PERTAMINA DAK} BALIKPAPAN

Edisi 1 Mei 1994.

3. Majalah Bazis No. 1/Syawal/1413 H, Samarinda

4. Republika, 4 Maret 1994.

5. Keputusan Bersama Menteri Dalam Negeri dan Menteri Agama RI tentang Pembinaan Bazis dan Petunjuk Pelaksanaannya, Proyek Pembinaan Sarana Keagamaan Islam, Zakat dan Wakaf Tahun Anggaran 1993/1994.

6. Proyek Pembinaan Zakat dan Wakaf, Pedoman Zakat Seri 1, Pola Pengembangan; 1983/1984. 